Goldschmidt 2021 Abstract

https://doi.org/10.7185/gold2021.7090

\section{New data on elements distribution in Bazhenov formation rocks for sedimentary reconstruction and secondary processes determination.}

\section{STEFANIA ROMANENKO ${ }^{1}$, MARIA FOMINA ${ }^{1}$, ANTON KALMYKOV $^{2}$, ANDREW BYCHKOV ${ }^{2}$ AND GEORGY KALMYKOV $^{2}$}

${ }^{1}$ National Intellectual Development Foundation

${ }^{2}$ Lomonosov Moscow State University

Presenting Author: sad_msu@mail.ru

Bazhenov formation is the main sours rock in West Siberia with complicated structure and unconventional reservoir interlayers, filled with shale oil. Variation of silica, carbonates, clay materials and other components content, and organic matter maturity uncertainty through depth and area lead to low veracity of region geological models. To increase their reliability sedimentary conditions and secondary processes should be investigated more intimately. It's well known that different elements content and their ratios allow to clarify the processes, that affected the formation evolvement. The lack of information on nature of elements distribution and complex of proceeded processes doesn't allow to unambiguously interpret the information. The aim of this research is to figure out which elements and ratios could be used for paleoreconstruction and chemostratigraphy of Bazhenov formation.

Numerous samples of Bazenov formation rocks and some overlying and underlying deposits from 32 wells were scrutinized by X-ray fluorescence analysis and inductively coupled plasma mass spectrometry. Rock composition and elements ratios were determined. Obtained results were combined with lithologic description and information on boundaries position, and the elements ratios, which characterize Bazhenov formation or special intervals were determined (Figure 1). It is established, that ratios $\mathrm{Al}_{2} \mathrm{O}_{3} / \mathrm{SiO}_{2} * 1000$ and $\mathrm{Ni} / \mathrm{Mo}$ are much lower in the formation than in overlying and underlying deposits. $\mathrm{V} / \mathrm{Cu}, \mathrm{Ni} / \mathrm{Al}, \mathrm{Na} / \mathrm{Al}, \mathrm{Mo} / \mathrm{Mn}$ and $\mathrm{Fe} / \mathrm{Mn}$ ratios increase on boundary between low and upper Bazhenov formation and turn to almost 0 in overlying deposits. $(\mathrm{Fe} / \mathrm{Mn}) / \mathrm{Ti}$ ratio increases in pack 5. Ni/Mo and $\mathrm{Al}_{2} \mathrm{O}_{3} / \mathrm{SiO}_{2} * 1000$ distributions are the same through all the Bazhenov formation, meanwhile $\mathrm{V} / \mathrm{Cu}$, $\mathrm{Fe} / \mathrm{Mn}$ and $(\mathrm{Fe} / \mathrm{Mn}) / \mathrm{Ti}, \mathrm{Na} / \mathrm{Al}, \mathrm{Ni} / \mathrm{Al}$ are the same only on the area of around 400 thousand $\mathrm{km}^{2}$ and highly differs in the north and south of West Siberia. The boundary between low and upper Bazhenov formation could be determined by significant peak in $\mathrm{Na} / \mathrm{Al}, \mathrm{Ni} / \mathrm{Mo}, \mathrm{Zr} / \mathrm{Al}, \mathrm{V} / \mathrm{Cr}, \mathrm{V} / \mathrm{Cu}, \mathrm{Mo} / \mathrm{Mn}$ ratios. Variety of most elements ratios on special areas can define different sedimentary conditions or secondary processes occurred in the formation. Investigations allow to determine same events on the whole area, do chemostratigraphic correlations. Further researches are necessary to reconstruct paleogeographic conditions for Bazhenov age.

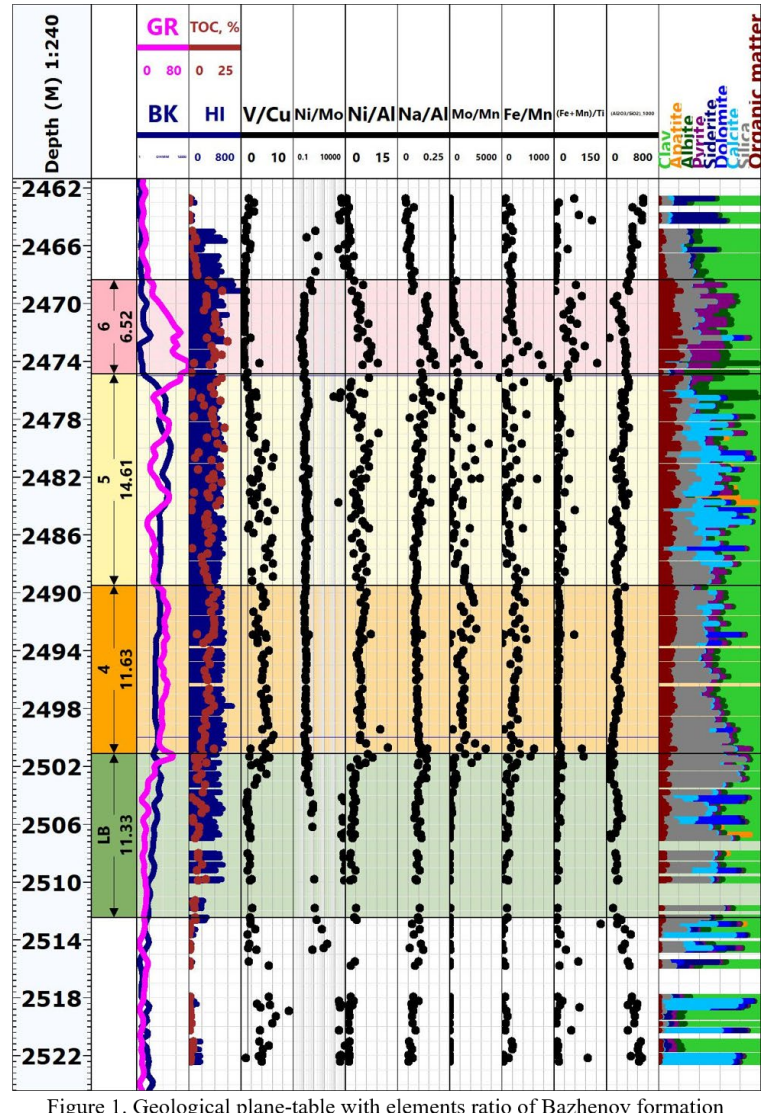

Figure 1. Geological plane-table with elements ratio of Bazhenov formation section for one well 